\title{
Protein Kinase C Gamma Type
}

National Cancer Institute

\section{Source}

National Cancer Institute. Protein Kinase C Gamma Type. NCI Thesaurus. Code 1111837.

Protein kinase C gamma type (697 aa, 78 kDa) is encoded by the human PRKCG gene.

This protein is involved in cellular signaling. 